\title{
L'Arco della Pace di Milano e la sua memoria storica: dal rilievo 3D e HBIM alla mixed reality (VR-AR)
}

\author{
Fabrizio Banfi \\ Daniela Oreni \\ Jacopo Alberto Bonini
}

\section{Abstract}

L'era digitale ha assunto un ruolo sempre più importante nel mondo del restauro, migliorando la gestione del patrimonio costruito e la diffusione dei suoi valori tangibili e immateriali. Secondo i recenti metodi sviluppati nei campi del rilievo 3D e del Building Information Modeling per edifici storici (HBIM), questa ricerca propone un flusso di lavoro digitale in grado di supportare la gestione digitale di uno dei monumenti italiani più importanti del Nord Italia: l'Arco della pace a Milano. La fotogrammetria digitale, il rilievo, il disegno e la modellazione 3D sono stati orientati allo sviluppo di un ambiente immersivo virtuale (mixed reality) in grado di interagire e raccontare la memoria storica di uno scenario complesso a diverse tipologie di utenti, da professionisti a turisti virtuali e studenti.
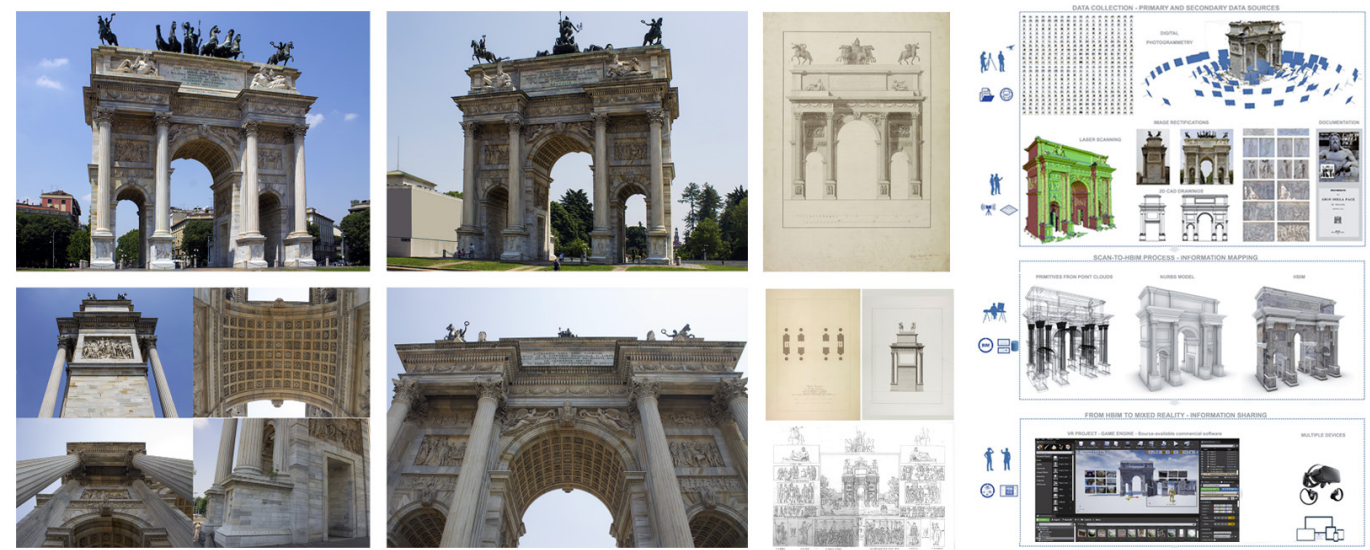


\section{Introduzione}

Negli ultimi anni la creazione di modelli digitali generati tramite un processo scan-to-BIM ha permesso di trasmettere, oltre le reali condizioni geometriche dell'edificio rilevato, anche un grande quantità di informazioni come analisi materiche, descrizioni dei materiali, patologie di degrado, caratteristiche fisiche e meccaniche dei materiali, fasi storiche e operazioni di restauro e cantiere [Oreni et al. 2014; Banfi 2020].

In questo contesto, una grande quantità di ricerche e studi applicati al patrimonio costruito hanno usufruito di questi strumenti digitali in grado di migliorare la gestione dell'intero ciclo di vita del manufatto, dal rilievo, al restauro e manutenzione programmata del bene storico [Brumana et al. 2020]. Come ben risaputo, le principali librerie BIM di default non permettono la creazione automatica e semi automatica di elementi storici complessi. Per questa ragione, negli ultimi anni, ricerche innovative e sviluppi informatici hanno permesso di andare oltre alla semplice rappresentazione di elementi semplici come muri ortogonali, pilastri, travi, coperture rettilinee, utilizzati principalmente per la generazione di edifici di nuova costruzione [Banfi 2020b; Previtali et al. 2019].

Di conseguenza, quando si tratta di realizzare progetti scan-to-bim complessi di edifici e monumenti storici, la modellazione digitale e il disegno tridimensionale risultano essenziali per la comprensione, generazione e gestione stessa del patrimonio costruito [Murphy et al. 2013].

Di fatti, la generazione dei modelli digitali storici (HBIM) richiede l'utilizzo di differenti tipologie dati:

- primary data sources (nuvole di punti proveniente da laser scanning e digital photogrammetry, orthophoto ad alta risoluzione, rilievo diretto e

- secondary data sources (documentazione storica, analisi materiche, analisi dei degradi, analisi strutturali).

La gestione e l'utilizzo appropriato di questi dati di conseguenza permette di gestire digitalmente l'edificio durante il suo ciclo di vita e incorporare nel progetto BIM una grande quantità di dati [Fai et al. 20 I I].
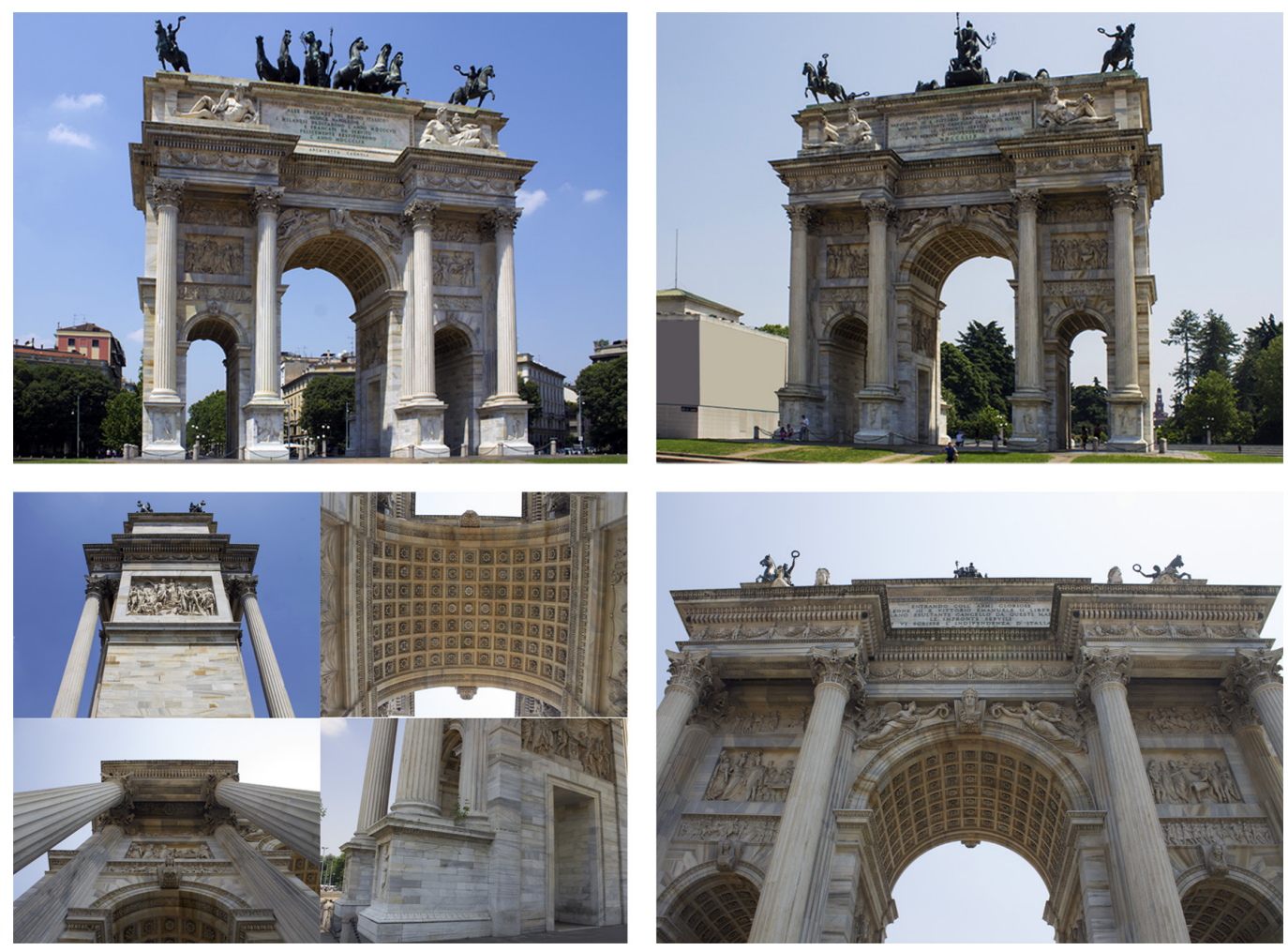


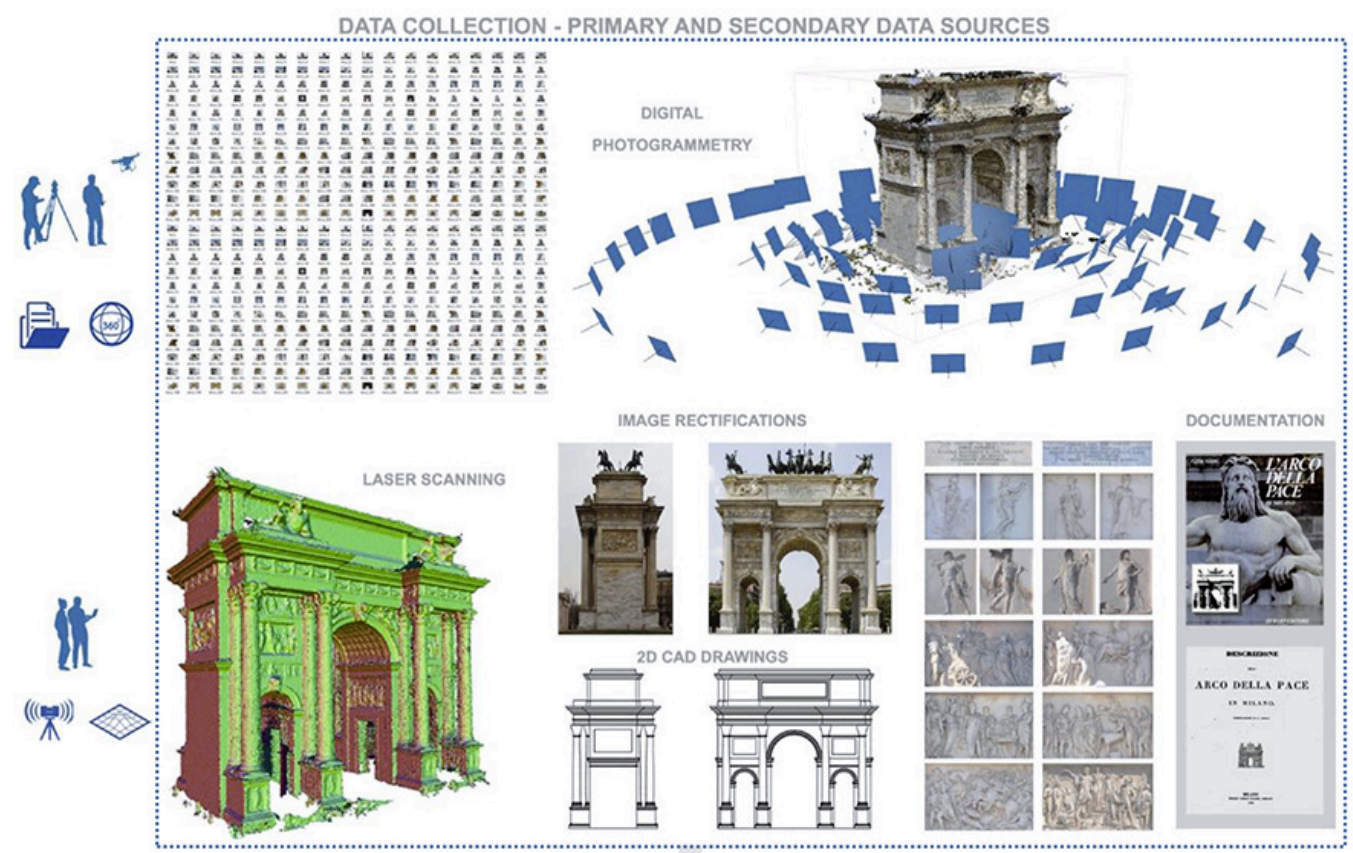

SCAN-TO-HBIMIRROCESS-INFORMATION MAPPING

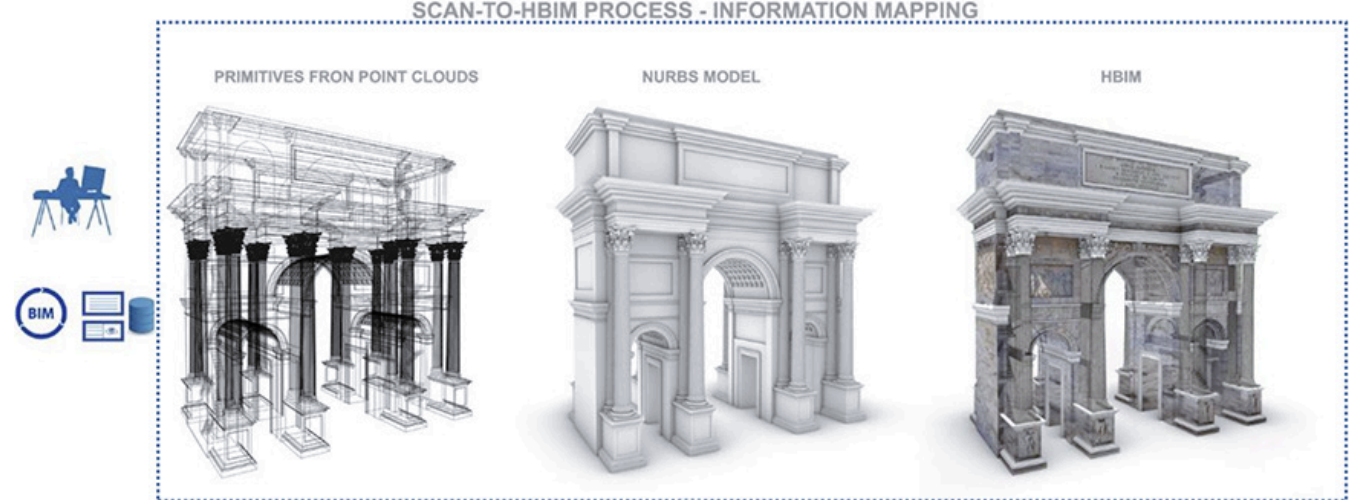

FROM HBIM TO MIXED REALITY - INFORMATION SHARINC

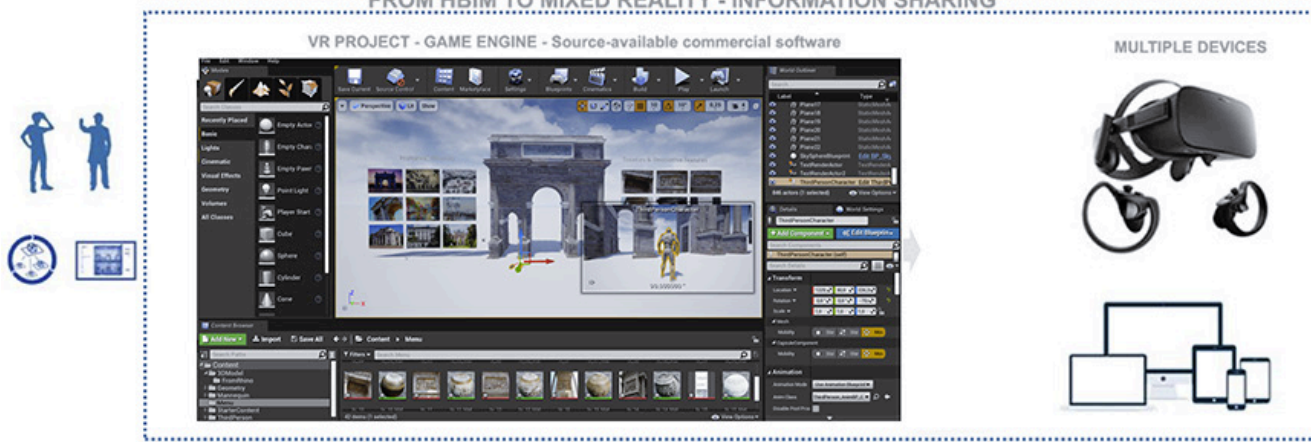

Fig. 2. II processo digitale applicato: dal rilievo 
I principali vantaggi riscontrati sono:

- raccolta e archiviazione, elaborazione, gestione di differenti tipologie di dati (dal semplice pdf al più complessi database BIM), [Bertocci et al. 2020; Liu et al. 20 I 2];

- condivisione dei modelli informativi tramite BIM cloud projects, favorendo il miglioramento della comunicazione tra i professionisti coinvolti nel ciclo di vita dell'edificio [Previtali et al. 2020; Redmond et al. 20 I2];

- elevati livelli di interoperabilità rispetto ai semplici elaborati bidimensionali (dwg and disegni vettoriali). I formati di scambio tridimensionali permettono di condividere modelli informativi complessi (modello e informazioni) a differenti tipologie di utenti [Andriasyan et al. 2020; Kiviniem et al. 20 I2];

- miglioramento delle analisi strutturali, elaborati di rilievo, progetto e restauro [Barazzetti et al. 20 15; Pepe et al. 2020];

- utilizzo dei modelli digitali HBIM per differenti tipologie di analisi, migliorando la gestione complessiva dell'intero ciclo di vita dell'edificio, dal cantiere, alle operazioni di restauro e manutenzione nel tempo [Della Torre 20 I7; Woodward et al. 2020];

- utilizzo dei modelli digitali HBIM per la creazione di progetti basati su tecniche di ultima generazione come VR-AR [Elgewely et al. 2020; Maha Pybus et al. 20 I9; Sdegno et al. 20 I8; Wong et al. 2020], trasformando modelli HBIM in un virtual story telling di uno dei principali monumenti storici italiani: l'Arco della pace di Milano.

Fig. 3. Disegni di Luigi Canonica per l'Arco della Pace, | $806-1838$ (da Ritratti di città in un interno: $<$ http://www.ritrattidicitta.it/arco-della-pace-1)>

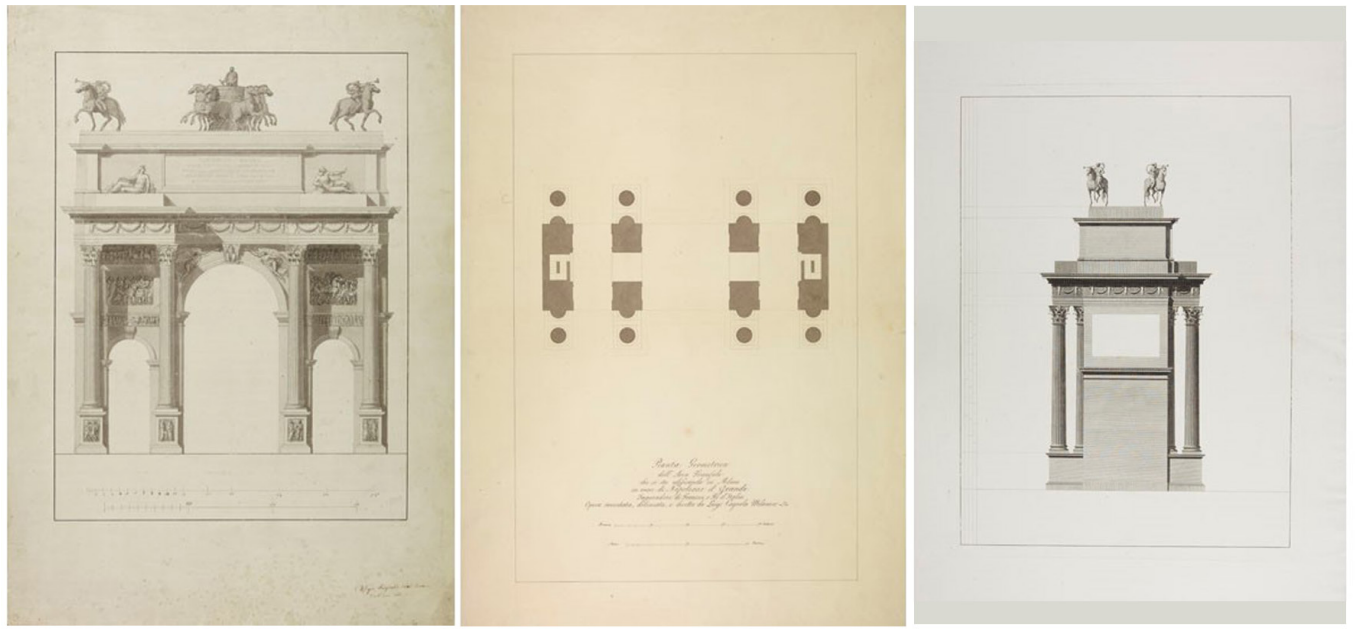

Note storiche sulla costruzione dell'Arco della Pace a Milano

Il primo progetto per la realizzazione dell'Arco del Sempione, all'entrata della Piazza d'Armi a Milano, risale al 1807 e venne eseguito dal Luigi Cagnola (fig.3). II progetto di questo edificio in marmo fu mutuato da un suo precedente disegno per un grandioso arco temporaneo in legno, innalzato presso Porta Orientale nel 1806, per celebrare l'ingresso in città degli sposi reali, il principe Eugenio e la principessa Amalia di Baviera. La prima posa per la realizzazione dell'arco trionfale avvenne il 14 ottobre 1807, sotto il dominio francese. Rispetto all'arco temporaneo "fu conservata l'integrità della composizione architettonica, e solamente variati ne furono i soggetti della scultura. Perciocchè se questi nel modello eretto a Porta Orientale alludevano a nozze, a trionfi di amore, di beltà e simili, nell'edificio in marmo dovevano in vece esprimere awvenimenti di storia e di guerra" [Sacchi I 828, p. 5]. Sebbene con alcune difficoltà legate al reperimento delle materie prime da costruzione, fino al I8I4 i lavori di realizzazione dell'edificio avanzarono dalle fondazioni fino alle parti più alte della struttura. Per quanto riguarda l'apparato decorativo, solo alcune parti basa- 
Fig. 4. Arco della Pace. Veduta verso la campagna con diseono dei bassorilievi in marmo Rein 1842. pp. 13-14] (seina 1842, pp. 13-14] (sinistra); con orth con orthophoto ad alta isoluzione degli appar decorativi (destra). mentali vennero portate a termine, tra cui gli otto bassorilievi allegorici posti sui piedistalli delle colonne verso la città [Lupi 1838, pp. 17, 18]. In seguito al ritorno degli austriaci in città, i lavori di costruzione dell'Arco vennero interrotti, con il rischio che ciò che fino a quel punto era stato costruito potesse essere demolito quale simbolo della precedente dominazione francese. Invece nel I 826 Francesco I Asburgo ne ordinò il completamento. La scelta finale del Cagnola ricadde sulla cava di Crevola d'Ossola per l'estrazione dei marmi da impiegarsi per la realizzazione delle otto lastre, degli otto basamenti, delle otto colonne in un unico pezzo e delle otto semicolonne "da farsi in 5 pezzi cadauna" [Grioni, Marchi 1999, p. 42]. II trasporto dalla cava al cantiere avvenne tra il 1828 e il I 829; le otto colonne in un unico pezzo, vennero trasportate presso l'Arco e "scannellate ai piedi del monumento stesso" [Lavori all'Arco della Pace in Milano I832, p. 3], per poi essere innalzate sui piedistalli nel |83|, attraverso l'impiego di "un cricco o macchina di ferro". || | 3 agosto | 833 l'architetto Cagnola morì e la direzione dei lavori passò al cavalier Carlo Londonio. L'ultimo lavoro ad essere portato a compimento, nel | 837, fu il posizionamento sull'attico della sestiga in bronzo con la statua della Pace [Lavori all'Arco della Pace in Milano I832, p. 12], i sei cavalli del Gran Carro di trionfo e i quattro cavalli d'angolo con le Vittorie sedute sopra. II I 0 settembre I 838 L'Arco della Pace venne inaugurato dall'Imperatore Augusto Ferdinando I [Grioni 1999].
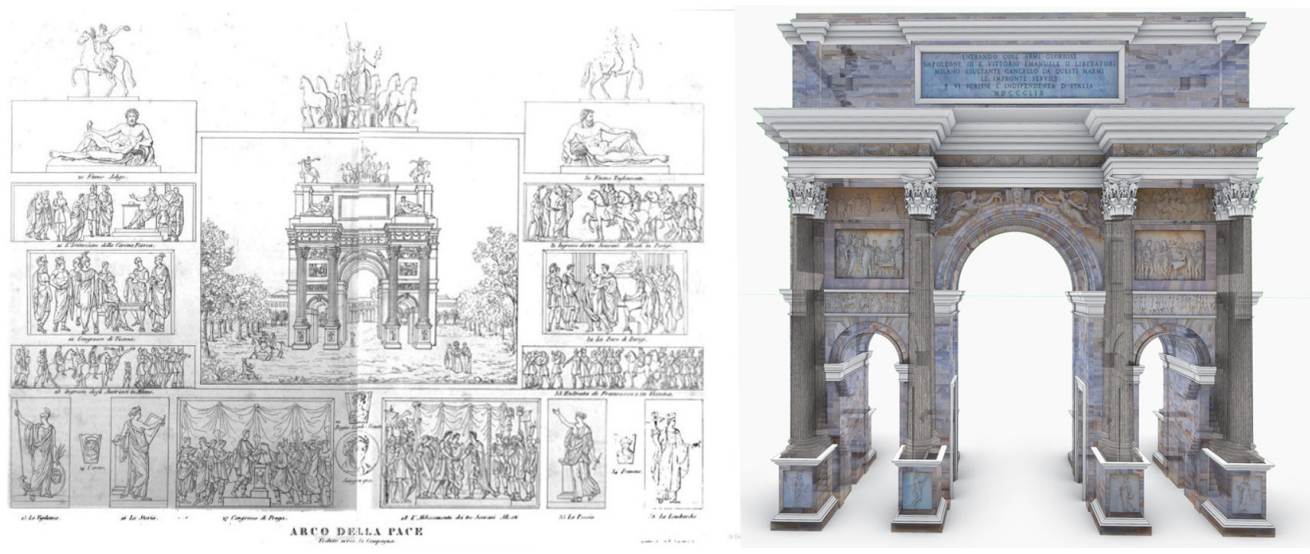

Il disegno dell'apparato decorativo in marmo e la sua funzione celebrativa: dal primo progetto del Cagnola per il napoleonico Arco del Sempione alle modifiche in Arco della Pace sotto il dominio austriaco

Oltre al progetto dell'Arco dal punto di vista architettonico, il Cagnola si occupò, fin dall'inizio, anche del disegno dell'apparato decorativo, degli ornamenti, dei bassorilievi in marmo e delle statue. Per quanto riguarda la traduzione in scultura delle sue raffigurazioni, Cagnola interpellò diversi celebri scultori dell'epoca, affidando loro l'esecuzione delle opere marmoree di maggior valore simbolico e celebrativo. Particolarmente interessante risulta proprio la vicenda della scelta dei soggetti allegorici e storici da rappresentare, definiti solo nel 1809 , dimostrando così la difficoltà nel trovare un accordo tra i vari soggetti coinvolti su questo fondamentale aspetto per un monumento dedicatorio.

Inevitabilmente le scelte dei temi da rappresentare subì un importante ripensamento nel momento in cui cambiò la committenza, da francese ad austriaca, e pertanto i valori da esprimere con il monumento diventarono altri. I cambiamenti dedicatori, a partire dal nome da "Arco di Trionfo" o "Arco del Sempione" dedicato a Napoleone in "Arco della Pace" per celebrare la "pace universale da tanto tempo da tutti i popoli desiderata" [Reina I842, p. 3], 
riguardarono principalmente gli undici bassorilievi che da quel momento avrebbero dovuto riferirsi alle campagne austriache tra il 1813 e il 1914 , scartando i precedenti temi quali quello dell'incoronazione del re di Roma.

Scrive Defendente Sacchi nel 1828: "Ai trofei di sanguinose conquiste sostituire le dolci rimembranze della pace; alle ferali rappresentazioni, le lusinghiere immagini dell'ordine, dell'abbondanza, delle scienze, delle arti, e di tutti què beni che la vera felicità delle genti costituiscono!"' [Sacchi I828, p. 6]. È in particolare nel testo di G. Reina, del I842, che vengono descritti con accuratezza e localizzati su tavole grafiche i singoli bassorilievi e il loro significato, riportati all'interno del modello HBIM (fig. 4).

Per quanto riguarda le cornici e gli elementi di decorazione, il modello del capitello corinzio venne disegnato Carlo Cattori, mentre Domenico Moglia si occupò di tutti i modelli in legno dei rosoni, degli ornati, delle sagome, delle cornici, del fregio, della trabeazione e di tutte le parti ornamentali "non appagandosi egli della sola composizione dè disegni, o del loro minuto dettaglio d'esecuzione; ma sul marmo stesso segnando col carbone o colla matita ciò che gli artefici lavorar doveano collo scarpello, e quasi la mano loro guidando" [Sacchi I828, p. 5] (fig. 5).

Le ultime modifiche all'apparato decorativo avvennero nel I 859 quando, dopo la vittoria di Magenta e l'ingresso trionfale a Milano di Napoleone III e diVittorio Emanuele II, acclamato re d'Italia, vennero cancellate le scritte dedicatorie a favore degli austriaci. Tra i più recenti interventi sull'Arco, fra il 2007 e il 2010 sono stati eseguiti lavori di pulitura delle superfici lapidee, di consolidamento e messa in sicurezza delle parti degradate e in fase di distacco (progettato e diretto dalla Soprintendenza Beni Architettonici e Paesaggistici di Milano). Un nuovo intervento di messa in sicurezza del monumento è oggi in corso d'opera, a seguito del distacco di pezzi di materiale lapideo e dalle importanti infiltrazioni d'acqua nelle parti sommitali dell'edificio [ $\mathrm{I}$; ì questa l'occasione di una serie di studi e approfondimenti diagnostici che la Soprintendenza sta facendo eseguire sul manufatto.

Fig. 5. Luigi Cagnola, 18061838, Dettaglio di ordine e trabeazione (da Ritratti di citta in un interno: <http:// www.ritrattidicitta.it/arcodella-pace- $\mid>$ ) (sinistra); HBIM and 3D details (destra).
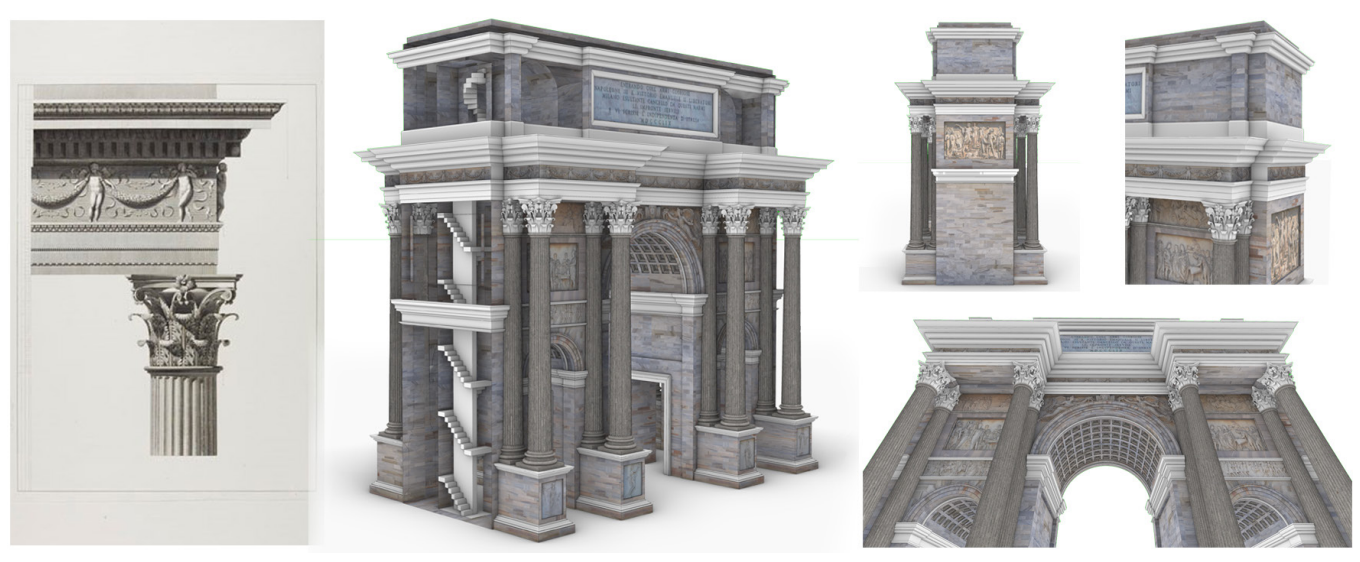

\section{La realtà virtuale quale strumento di racconto di una trasformazione dell'apparato decorativo per scopi celebrativi variati}

Le vicende costruttive e decorative dell'Arco non sono il risultato di scelte esclusivamente stilistiche, architettoniche e tecnologiche, ma soprattutto politiche ed economiche. Tali scelte hanno portato a continue e sostanziali modifiche nel tempo dell'apparato decorativo, a seconda delle variate esigenze celebrative. Gli strumenti della realtà virtuale e aumentata possono oggi rappresentare un valido strumento di valorizzazione e divulgazione di informazioni storiche e costruttive sulla fabbrica, anche ad oggi non più immediatamente riconoscibili, attraverso l'impiego di una tecnologia sempre più accessibile e user friendly. Diversi e molteplici sono le finalità dell'impiego di tali strumenti, a partire da quelli didattici e turistici, fino alla costruzione di ambienti di lavoro implementabili e aggiornabili, utilizzabili anche da 
parte dei tecnici impegnati nella manutenzione costante di questo manufatto, che tanti problemi presenta dal punto di vista della conservazione delle superfici marmoree scolpite. Per questi motivi sono state indagate le principali tecniche di modellazione avanzata, i principali software di scambio tra applicazioni BIM e piattaforme gaming e testati i principali dispositivi $V R$ e AR con l'obiettivo generale di facilitare e rendere più interessante e accessibile la scoperta della memoria storica del monumento. Grazie a una logica open source di sviluppo è stato possibile sviluppare un progetto VR-AR editabile in qualsiasi momento, permettendo un ampliamento informativo del storytelling oltre a quello proposto in questo studio.

Interactive Menu

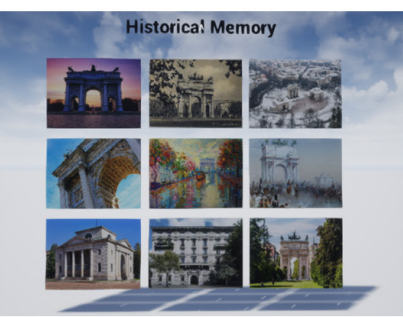

VR environment design

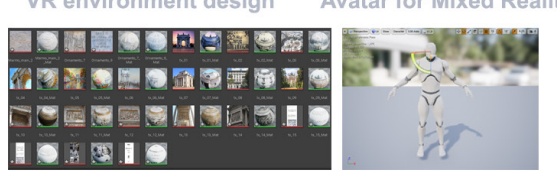

Visual seripting

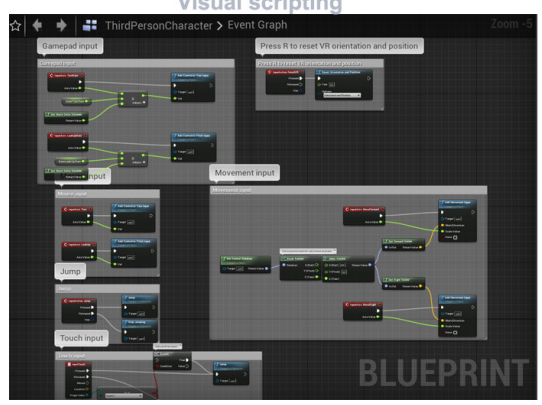

VR environment

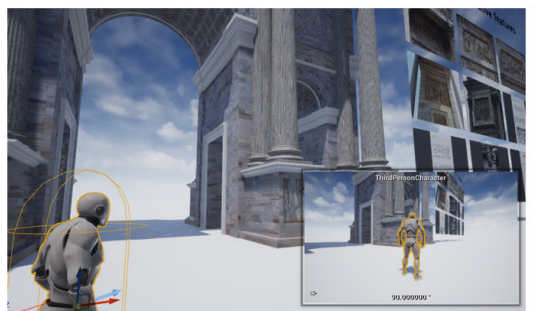

Interactive Menu

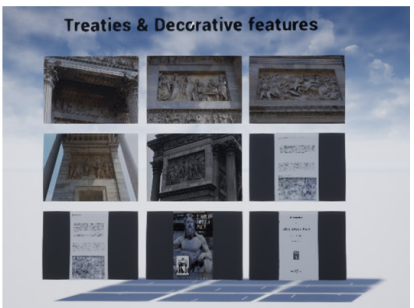

Fig. 6. II progetto Mixed Reality dell' Arco della Pace di Milano and its historic memory: from mixed reality (VR-AR).

I motivi che hanno condotto alla selezione di dispositivi e applicazioni specifiche sono i seguenti:

- disegno 3D e modellazione free-form: sono stati utilizzati specifici requisiti generativi scanto-BIM come i gradi di generazione 9 e 10 e algoritmi NURBS, i quali hanno permesso di creare primitive geometriche e modelli $3 \mathrm{D}$ interpolando direttamente i punti che compongono le scansioni e le nuvole di punti [Banfi 2017].

- modellazione object-oriented: grazie all'utilizzo dell'applicazione BIM più utilizzata nel mondo delle costruzioni (Autodesk Revit) è stato possibile applicare in modo corretto i vari gradi di generazione, trasformando modelli NURBS in modelli parametri informativi;

- mixed reality: sviluppo di un progetto VR-AR attraverso un sistema di scripting di gioco completo basato sul concetto di utilizzare un'interfaccia composta da nodi per creare elementi di gioco dall'interno di Unreal Engine Editor. Come succede con molti linguaggi di scripting, all'interno del mtore vengono definite classi orientate agli oggetti o oggetti stessi. Grazie alla sua flessibilità offre la possibilità agli esperti BIM di utilizzare virtualmente l'intera gamma di strumenti e concetti e generalmente disponibile solo per i programmatori. Grazie alla sua flessibilità consente agli esperti BIM di utilizzare virtualmente l'intera gamma di strumenti e concetti generalmente accessibili soltanto ai programmatori

- VR headset: I vantaggi riscontrati dal Oculus RIFT S e Quest hanno permesso di andare oltre a una semplice visualizzazione desktop. Grazie all'integrazione di sensori di movimenti 
nel corpo della maschera $V R$ e a comandi in grado di riproporre le principali azioni delle dita delle mani (presa, rilascio, selezione, lancio etc.) è stato possibile aumentare i livelli di interattivi del modello HBIM. Sono stati realizzati pannelli informativi, punti di controllo, e oggetti interattivi in grado di interagire direttamente con le azioni dell'utente virtuale (fig. 6). - dispositivi mobili: la piattaforma VR infine ha permesso di selezionare le principali tecniche di conversione del progetto sviluppato interamente in UE4. Grazie alle principali funzioni di packaging il progetto MR è stato convertito in una e vera e propria app per dispositivi IOS e Android.

\section{Conclusioni}

Negli ultimi anni, grazie all'interazione di processi scan to bim è stato possibile andare oltre la tradizionale rappresentazione bidimensionale, aumentando la condivisione e la comunicazione delle informazioni durante il ciclo di vita degli edifici. Grazie ai benefici riscontrati negli ultimi anni in questo specifico campo di applicazione, questo studio ha ottimizzato l'utilizzo dei modelli HBIM con lo scopo di raccontare la storia del monumento sia a distanza (desktop, headset VR) sia in sito (mobile phone e tablet), fornendo uno strumento di studio e analisi ad esperti del settore come restauratori, manutentori, progettisti e sviluppando un ambiente immersivo in grado di far interagire l'utente virtuale con il modello del monumento e le sue informazioni, diventando un vero e proprio strumento educativo e di intrattenimento.

\section{Note}

[I] Si ringrazia a tal proposito l'architetto Rebecca Fant per le preziose informazioni fornite, relative al cantiere di messa in sicurezza in corso (gennaio 2020).

\section{Riferimenti bibliografici}

Andriasyan Mesrop et al. (2020). From Point Cloud Data to Building Information Modelling: An Automatic Parametric Workflow for Heritage. In Remote Sensing, 2020, 12.7: 1094.

Banfi Fabrizio (2017). BIM orientation: Grades of generation and information for different type of analysis and management process. In International Archives of the Photogrammetry, Remote Sensing \& Spatial Information Sciences, $2017,42$.

Banfi Fabrizio (2019). Hbim Generation: Extending Geometric Primitives and Bim Modelling Tools for Heritage Structures and Complex Vaulted Systems. In: 27th CIPA International Symposium-Documenting the Past for a Better Future. International Society for Photogrammetry and Remote Sensing, pp. I39- 148.

Banfi Fabrizio (2016). Building information modelling-A novel parametric modeling approach based on 3D surveys of historic architecture. In Euro-Mediterranean Conference. Springer, Cham, pp. I I 6- 127.

Barazzetti Luigi et al. (20I5). Cloud-to-BIM-to-FEM: Structural simulation with accurate historic BIM from laser scans. In Simulation Modelling Practice and Theory, 2015, 57: 71-87.

Bertocci Stefano et al. (2020). The Kyrenia castle, an approach to digital documentation in the Cyprus island. In Proceedings of the 23rd International Conference on Cultural Heritage and New Technologies. Museen der Stadt Wien-Stadtarchäologie.

Brumana Raffaella et al. (2020). Survey and Scan to BIM Model for the Knowledge of Built Heritage and the Management of Conservation Activities. In Digital Transformation of the Design, Construction and Management Processes of the Built Environment. Springer, Cham, pp. 391-400.

Della Torre Stefano (2017). Un bilancio del progetto BHIMM. In Modellazione e gestione delle informazioni per il patrimonio edilizio esistente. Ingenio, pp. I0- 16.

Elgewely Maha, Nadim Wafaa (2020). Immersive Virtual Reality Environment for Construction Detailing Education Using Building Information Modeling (BIM). In The IOth International Conference on Engineering, Project, and Production Management. Springer, Singapore, pp. 101-1 12.

Fai Stephen et al. (20I I). Building information modelling and heritage documentation. In Proceedings of the 23rd International Symposium, International Scientific Committee for Documentation of Cultural Heritage (CIPA), Prague, pp. I2-I6.

Kiviniemi Arto et al. (20।8). Review of the development and implementation of IFC compatible BIM.

Liu Rui, Issa Raja R.A. (20I2). Automatically updating maintenance information from a BIM database. In Computing in Civil Engineering 2012, pp. 373-380. 
Murphy Maurice, McGovern Eugene, Pavia Sara (2013). Historic Building Information Modelling-Adding intelligence to laser and image based surveys of European classical architecture. In ISPRS journal of photogrammetry and remote sensing, 20 I3, 76: 89-102.

Oreni Daniela et al. (20|4). Survey turned into HBIM: the restoration and the work involved concerning the Basilica di Collemaggio after the earthquake (L'Aquila).In ISPRS annals of the photogrammetry, remote sensing and spatial information sciences, 2014, 2.5: 267.

Pepe Massimiliano et al. (2020). An Efficient Pipeline to Obtain 3D Model for HBIM and Structural Analysis Purposes from 3D Point Clouds. In Applied Sciences, 2020, 10.4: 1235

Previtali Mattia, Banfi Fabrizio (2018). Towards the Definition of Workflows for Automation in HBIM Generation. In EuroMediterranean Conference. Springer, Cham, pp. 52-63.

Previtali Mattia et al. (2020). An Ontology-Based Representation of Vaulted System for HBIM. In Applied Sciences, 2020, I0.4: 1377.

Pybus Cailen et al. (2019). New realities for Canada's parliament: a workflow for preparing heritage bim for game engines and virtual reality. In International Archives of the Photogrammetry, Remote Sensing \& Spatial Information Sciences.

Redmond Alan et al. (2012). Exploring how information exchanges can be enhanced through Cloud BIM. In Automation in construction, 2012, 24: 175-183.

Sdegno Alberto et al. (2018). Advanced Simulation of Frank Lloyd Wright's Fallingwater: Digital Reconstruction and Virtual Reality. In International and Interdisciplinary Conference on Digital Environments for Education, Arts and Heritage. Springer, Cham, pp. 587-596.

Woodward Alexa, Heesom David (2020). Implementing HBIM on conservation heritage projects: Lessons from renovation case studies.

Wong Jing-Ying et al. (2020). BIM-VR Framework for Building Information Modelling in Engineering Education. In International Journal of Interactive Mobile Technologies (iJIM), 2020, 14.06: I5-39.

Autori

Fabrizio Banfi, Politecnico di Milano, fabrizio.banfi@polimi.it

Daniela Oreni, Politecnico di Milano, daniela.oreni@polimi.jt

Jacopo Alberto Bonini, Politecnico di Milano, jacopoalberto.bonini@polimi.it

Per citare questo capitolo: Banfi Fabrizio, Oreni Daniela, Bonini Alberto Jacopo (2020). L'arco della Pace di Milano e la sua memoria storica: dal rilievo 3D e HBIM alla mixed reality (VR-AR)/The Arch of Peace of Milan and its historic memory: from 3D survey and HBIM to mixed reality (VR-AR). In Arena A., Arena M., Brandolino R.G., Colistra D., Ginex G., Mediati D., Nucifora S., Raffa P. (a cura di). Connettere. Un disegno per annodare e tessere. Atti del $42^{\circ}$ Convegno Internazionale dei Docenti delle Discipline della Rappresentazione/Connecting. Drawing for weaving relationships. Proceedings of the 42th International Conference of Representation Disciplines Teachers. Milano: FrancoAngeli, pp. I 660- 1677. 


\title{
The Arch of Peace of Milan and its Historic Memory: from 3D Survey and HBIM to Mixed Reality (VR-AR)
}

\author{
Fabrizio Banfi \\ Daniela Oreni \\ Jacopo Alberto Bonini
}

\section{Abstract}

The digital age has assumed an increasingly important role in the world of restoration, improving the management of the built heritage and the spread of its tangible and intangible values. According to recent methods developed in the fields of 3D surveying and Building Information Modeling for historic buildings (HBIM), this research proposes a digital workflow capable of supporting the digital management of one of the most important Italian monuments in Northern Italy: the Arch of Peace in Milan. Digital photogrammetry, survey, drawing and 3D modelling have been oriented towards the development of a virtual immersive environment (mixed reality) capable of interacting and telling the historical memory of a complex scenario for different types of users, from professionals to virtual tourists and students.

\section{Keywords}

scan-to-BIM, built heritage, historic building information modelling (HBIM), virtual storytelling, mixed reality.
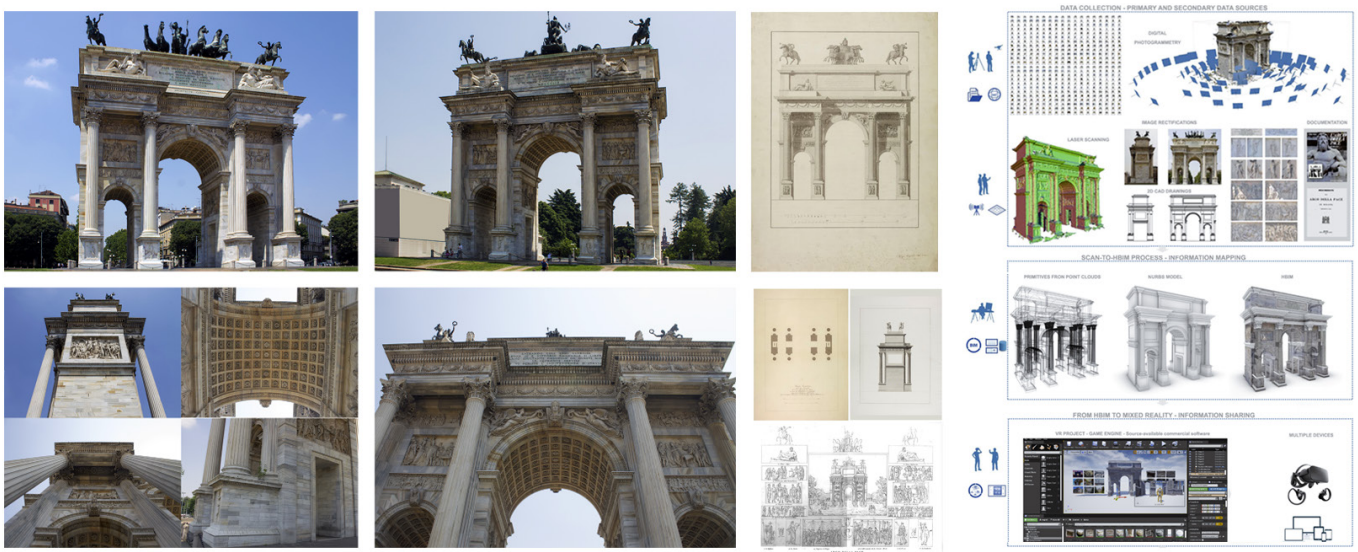


\section{Introduction}

In recent years the creation of digital models generated through a scan-to-BIM process has made it possible to transmit, in addition to the actual geometric conditions of the detected building, also a large amount of information such as material analyzes, descriptions of materials, degradation pathologies, physical and mechanical characteristics of the materials, historical phases and restoration and building site operations [Oreni et al. 20 I 4; Banfi 20 I6]. In this context, a large amount of research and studies applied to the built heritage have made use of these digital tools capable of improving the management of the entire life cycle of the building, from the survey, to the restoration and scheduled maintenance of the historic property [Brumana et al. 2020]. As is well known, the main default BIM libraries do not allow the automatic and semi-automatic creation of complex historical elements. For this reason, in recent years, innovative research and IT developments have made it possible to go beyond the simple representation of simple elements such as orthogonal walls, pillars, beams, rectilinear roofs, mainly used for the generation of new buildings [Previtali et al. 20 I9; Banfi 2020].

Consequently, when it comes to carrying out complex scan-to-bim projects of historic buildings and

In fact, the generation of historical digital models (HBIM) requires the use of different data types:

- primary data sources (point clouds from laser scanning and digital photogrammetry, high-resolution orthophoto, direct survey and

- secondary data sources (historical documentation, material analysis, degradation analysis, structural analysis).

The management and appropriate use of these data consequently allows you to digitally manage the building during its life cycle and incorporate a large amount of data into the BIM project [Fai et al. $201 \mathrm{I}$ ].
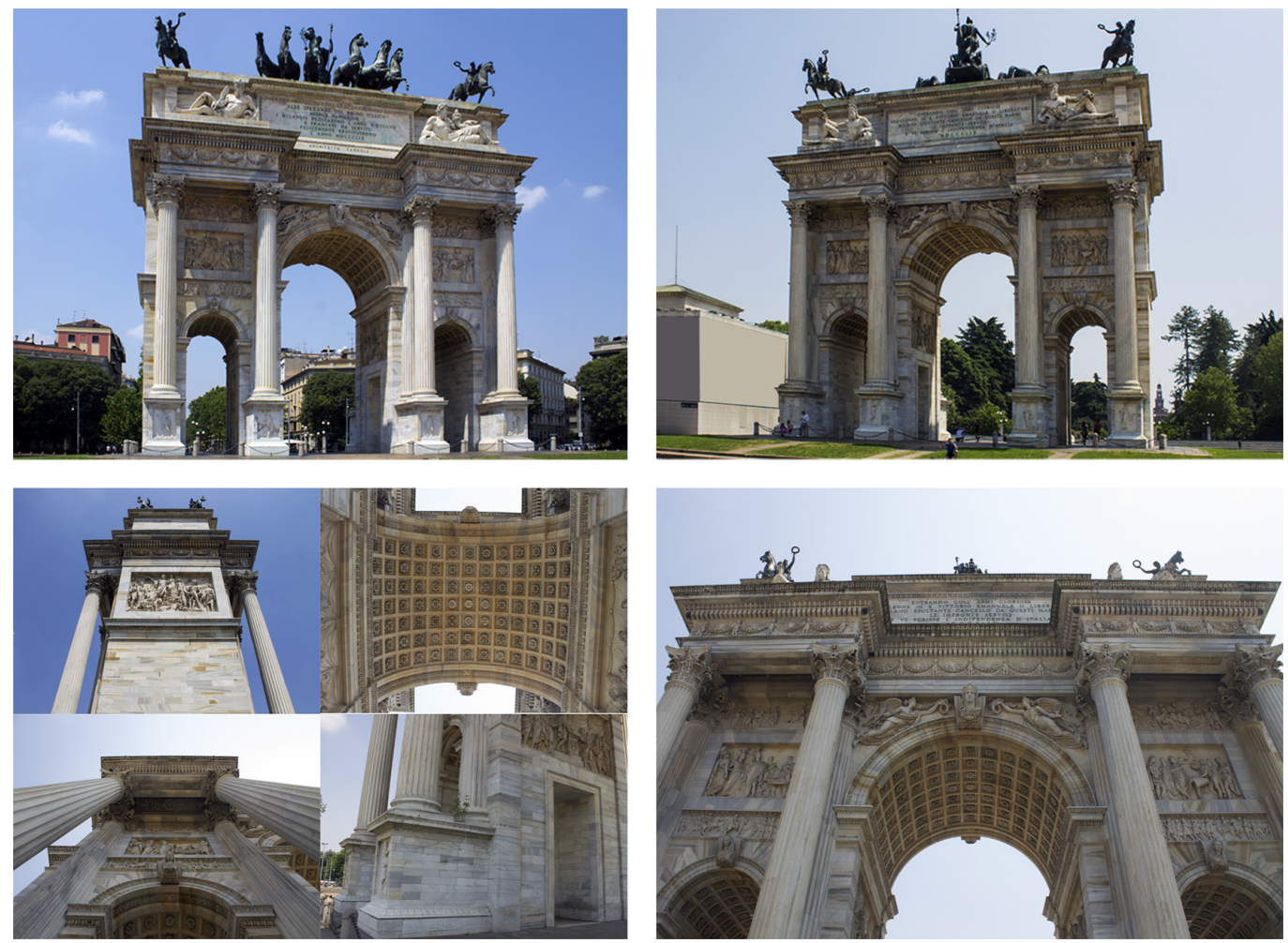


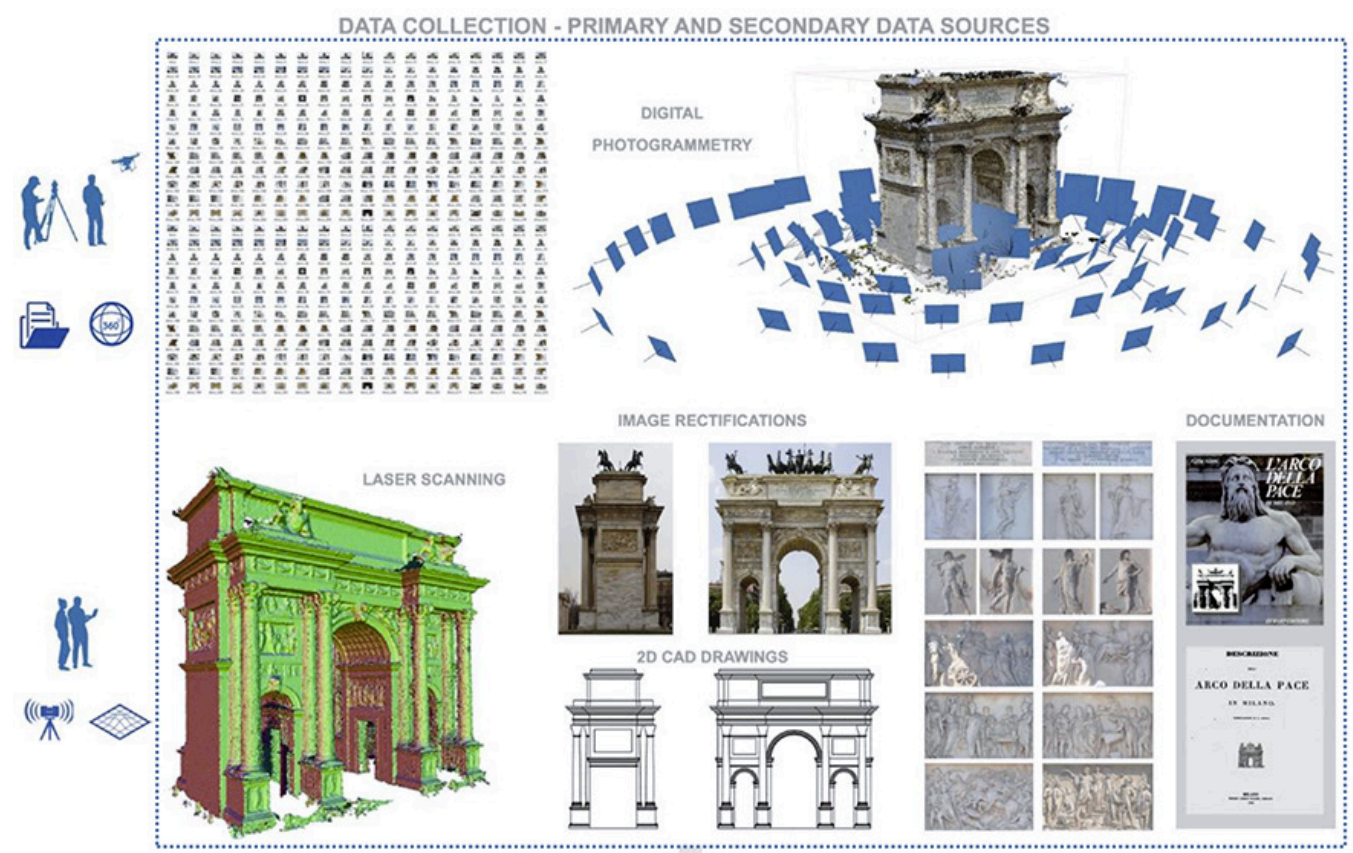

SCAN-TO-HBIMIRROCESS-INFORMATION MAPPING

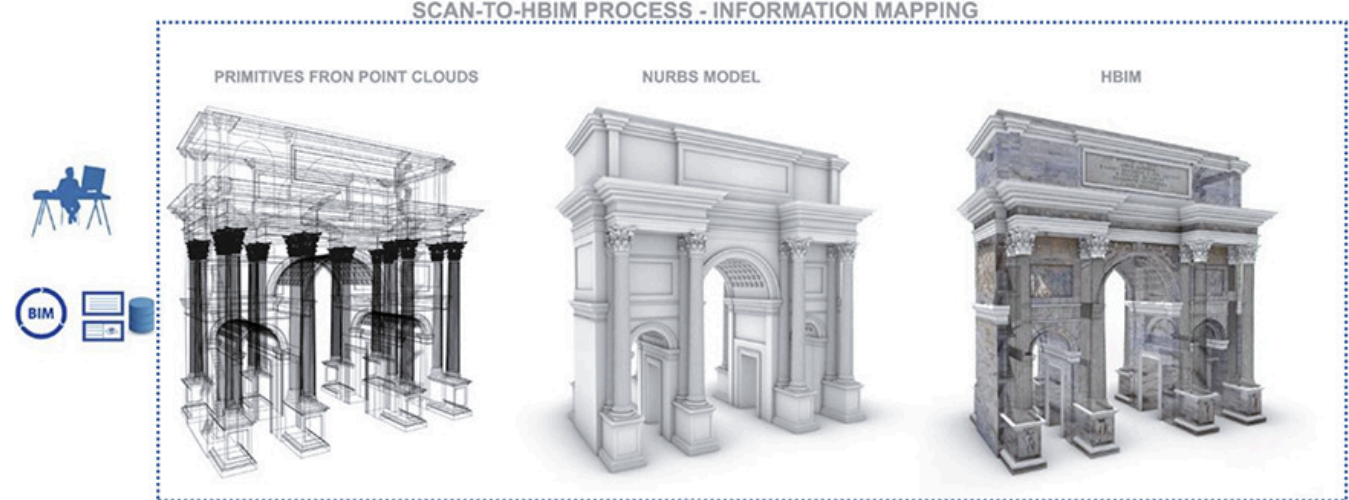

FROM HBIM TO MIXED REALITY - INFORMATION SHARINC

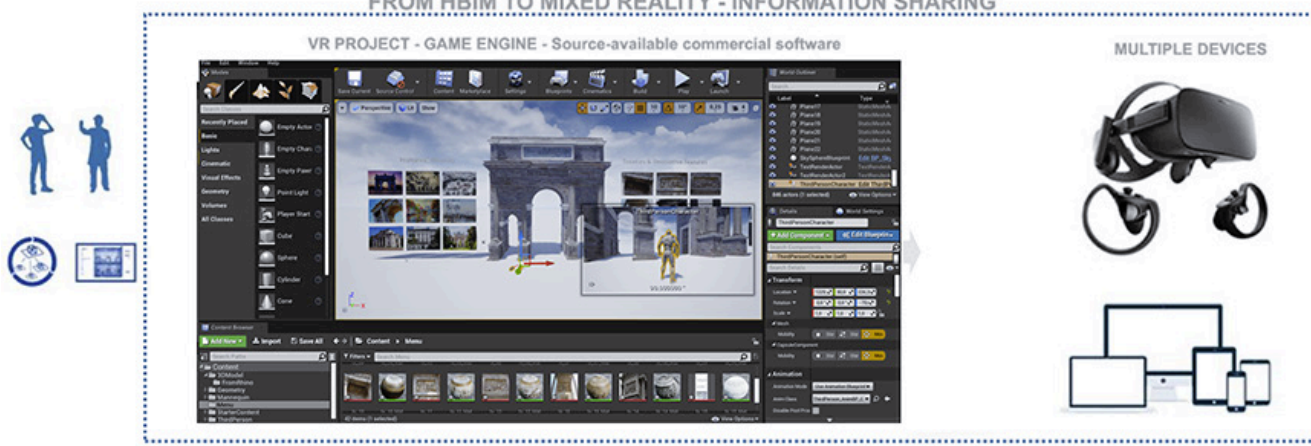


Fig. 3. Disegni di Luig Canonica per l'Arco della Pace, 1806-1838 (from Ritratti di città in un interno: <http://www. ritrattidicitta.it/arco-della-pace- $\mid>$ ).
The main advantages found are:

- collection and storage, processing, management of different types of data (from simple pdf to more complex BIM databases) [Liu et al. 20 I2];

- sharing of information models through BIM cloud projects, promoting the improvement of communication between the professionals involved in the building life cycle [Redmond et al. 20I2];

- high levels of interoperability compared to simple two-dimensional drawings (dwg and vector drawings). The three-dimensional exchange formats allow to share complex information models (model and information) to different types of users such as architects, surveyors, engineers but also to restorers, archaeologists and structural engineers able to optimize the geometric and semantic data included in the HBIM project (Kiviniem et al. 2012); - improvement of structural analyzes, elaborate surveys, design and restoration [Barazzetti et al. 20I5];

- use of HBIM digital models for different types of analysis, improving the overall management of the entire life cycle of the building, from the construction site to restoration and maintenance operations over time [Della Torre 2017];

- use of HBIM digital models for the creation of projects based on the latest generation techniques such as Virtual and Augmented reality (VR-AR), [Pybus et al. 2019], transforming $\mathrm{HBIM}$ models into a virtual story telling of one of the main Italian historical monuments: the Arch of peace in Milan.

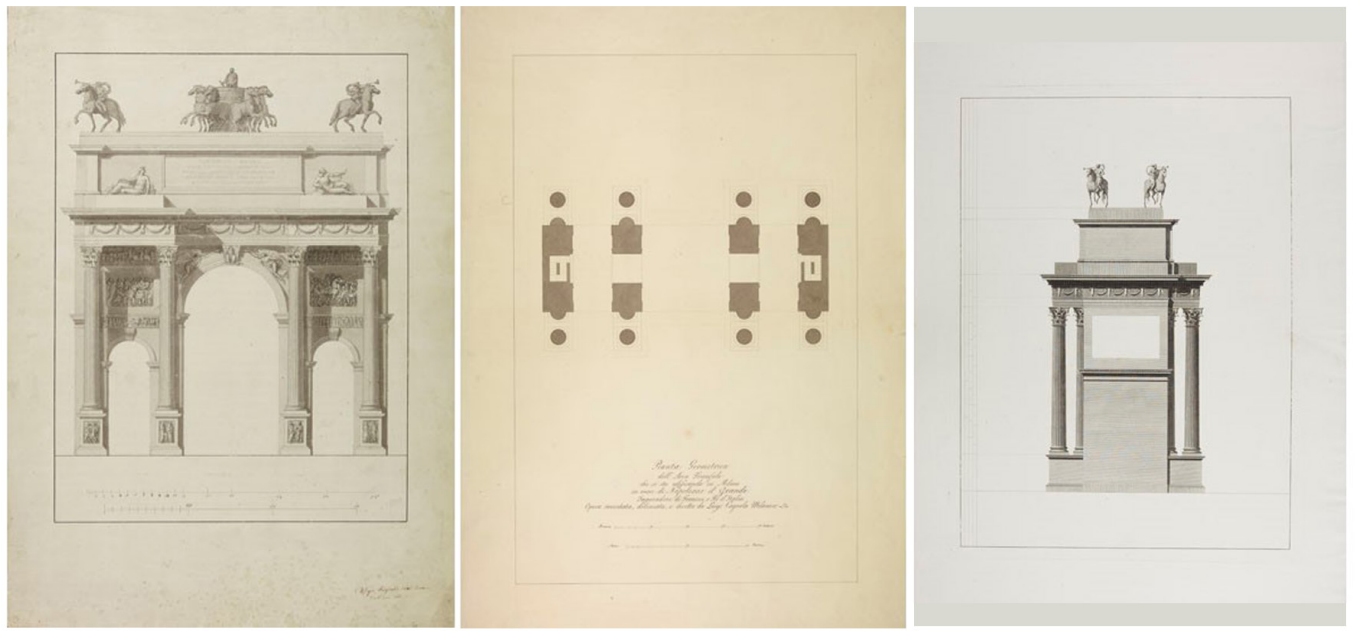

Historical notes on the construction of the Arco della Pace in Milan

The first project for the construction of the Arco del Sempione, at the entrance to the Piazza d'Armi in Milan, dates back to 1807 and was carried out by Luigi Cagnola (fig. 3). The project for this marble building was borrowed from a previous design for a grandiose temporary wooden arch, erected at the Eastern Gate in 1806, to celebrate the entry into the city of the royal spouses, Prince Eugene and Princess Amalia of Bavaria. The first installation for the realization of the triumphal arch took place on October |4, | 807, under French rule. Compared to the temporary arch "the integrity of the architectural composition was preserved, and only the subjects of the sculpture varied. Because if these in the model erected at the Eastern Gate alluded to marriage, to triumphs of love, beauty and the like, in the marble building they had to express events of history and war instead"'[Sacchi I828, p. 5]. Although with some difficulties related to the procurement of construction raw materials, until 1814 the construction work on the building advanced from the foundations to the highest parts of the structure. As for the decorative apparatus, only a few base parts were 
Fig. 4. Arch of Peace. View towards the countryside, with a drawing of the marble bas-reliefs [Reina 1842 pp. |3-14] (left); HBIM model mapped with high resolution orthophoto of the decorative devices (right) completed, including the eight allegorical bas-reliefs placed on the pedestals of the columns towards the city [Lupi 1838, pp. 17, 18]. Following the return of the Austrians to the city, the construction of the Arch was interrupted, with the risk that what had been built up to that point could be demolished as a symbol of the previous French domination. Instead in 1826 Francis I Habsburg ordered its completion. The final choice of Cagnola fell on the Crevola d'Ossola quarry for the extraction of the marble to be used for the construction of the eight slabs, the eight bases, the eight columns in one piece and the eight half-columns "to be made in 5 pieces each" [Grioni, Marchi 1999, p. 42]. The transport from the quarry to the construction site took place between 1828 and 1829; the eight columns in one piece were transported to the Arch and "fluted at the foot of the monument itself" [Lavori all'Arco della Pace in Milano I832, p. 3], to then be raised on pedestals in I831, through the use of "a jack or iron machine". On 13 August I 833 the architect Cagnola died and the direction of the work passed to cavalier Carlo Londonio. The last work to be completed, in I 837, was the positioning on the attic of the bronze sestiga with the statue of Peace(Lavori all'Arco della Pace in Milano 1832, p. 12), the six horses of the triumphant Grand Chariot and the four corner horses with the Victories seated above. On 10 September 1838 the Arco della Pace was inaugurated by Emperor Augusto Ferdinando I [Grioni 1999].
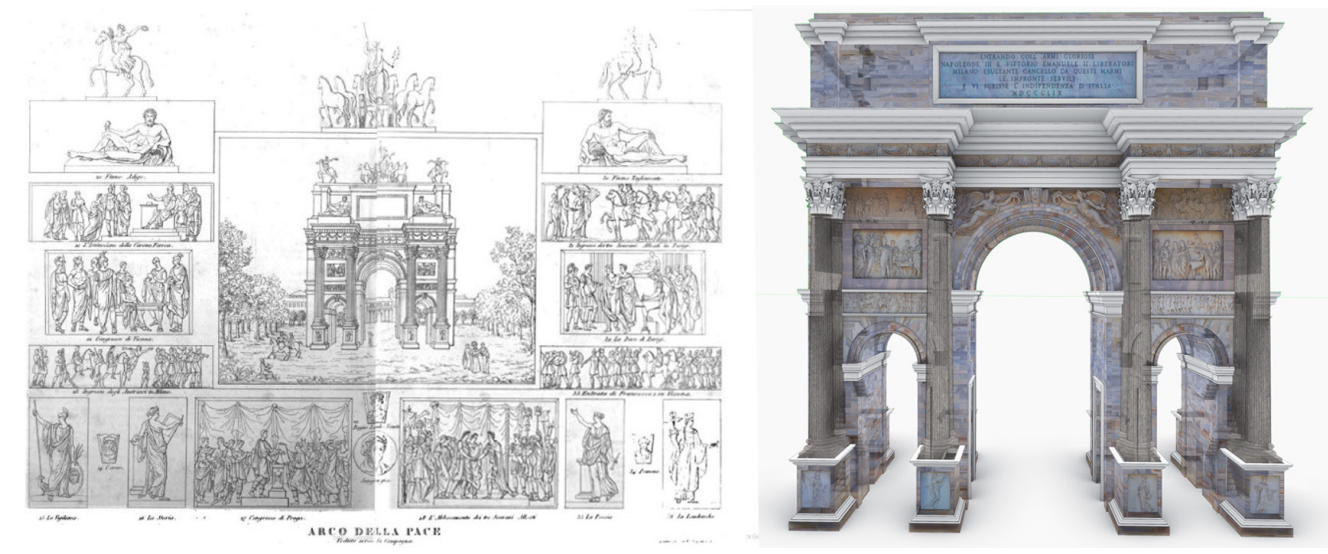

The design of the marble decorative apparatus and its celebratory function: from the first project by Cagnola for the Napoleonic Arco del Sempione to the modifications in Arco della Pace under Austrian rule

In addition to the architectural project from the architectural point of view, Cagnola also dealt with the design of the decorative apparatus, ornaments, marble bas-reliefs and statues from the outset. As for the translation into sculpture of his representations, Cagnola asked several famous sculptors of the time, entrusting them with the execution of the marble works of greater symbolic and celebratory value. Particularly interesting is the story of the choice of allegorical and historical subjects to represent, defined only in 1809, thus demonstrating the difficulty in finding an agreement between the various subjects involved on this fundamental aspect for a dedicatory monument.

The choices of the themes to be represented underwent an important rethinking when the client changed from French to Austrian, and therefore the values to be expressed with the monument became others. The dedicatory changes, starting from the name from "Arco di Trionfo" or "Arco del Sempione" dedicated to Napoleon in "Arco della Pace" to celebrate universal peace for a long time by all the peoples desired [Reina I842, p. 3], mainly con- 
cerned the eleven bas-reliefs that from that moment should have referred to the Austrian countryside between 1813 and 1914, discarding previous themes such as that of the coronation of the king of Rome.

Defendente Sacchi wrote in 1828: "To the trophies of bloody conquests replace the sweet remembrances of peace; to the feral representations, the flattering images of order, abundance, science, the arts, and all these goods that the true happiness of the people constitute!" 'Sacchi I828, p. 6]. It is in particular in the text of G. Reina, of I842, that the individual bas-reliefs and their meaning, reported within the HBIM model, are accurately described and localized on graphic tables (fig. 4).

As for the frames and decoration elements, the model of the Corinthian capital was designed by Carlo Cattori, while Domenico Moglia took care of all the wooden models of the rose windows, the ornaments, the shapes, the frames, the frieze, the entablature and of all the ornamental parts "not satisfying himself only with the composition of the drawings, or with their minute detail of execution; but on the marble itself, marking with charcoal or pencil what the craftsmen had to work with a chisel, and almost guiding their hand" [Sacchi I828, p. 5] (fig. 5).

The last changes to the decorative apparatus took place in 1859 when, after the victory of Magenta and the triumphal entry into Milan of Napoleon III and Vittorio Emanuele II, acclaimed king of Italy, the dedicatory writings in favor of the Austrians were canceled. Among the most recent interventions on the Arch, between 2007 and 2010 work was carried out on the cleaning of the stone surfaces, consolidation and safety of degraded and detaching parts (designed and directed by the Superintendency of Architectural and Landscape Heritage of Milan). A new intervention to secure the monument is currently underway, following the detachment of pieces of stone material and the important water infiltrations in the top parts of the building [I]; this is the occasion for a series of studies and diagnostic investigations that the Superintendency is carrying out on the artefact.

Fig. 5. Detail of order and entablature, Luigi Cagnola 1806- 838 (Portraits of the city in an interior. $<$ http://www.ritrattidicitta. it/arco-della-pace- $\mid>$ ), (left); HBIM and 3D details (right).
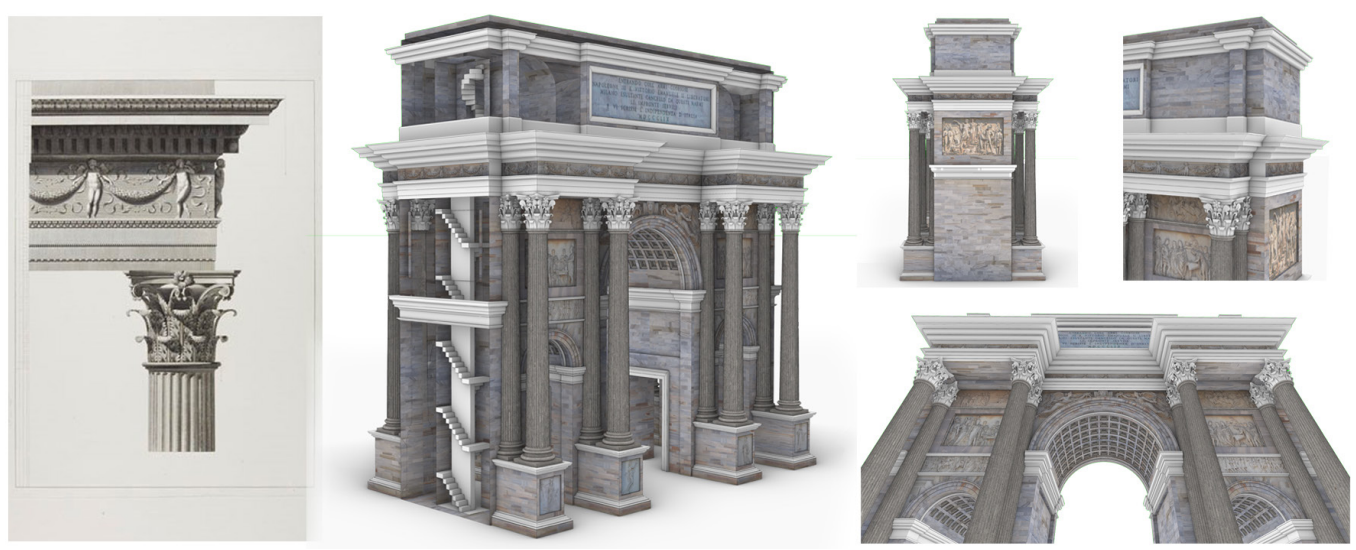

\section{Virtual reality as a tool for narrating a transformation of the decorative apparatus for various celebratory purposes}

The construction and decorative events of the Arch are not the result of exclusively stylistic, architectural and technological choices, but above all political and economic. These choices have led to continuous and substantial changes over time of the decorative system, according to the various celebratory needs. The tools of virtual and augmented reality can today represent a valid tool for the enhancement and dissemination of historical and constructive information on the factory, even today no longer immediately recognizable, through the use of increasingly accessible and user-friendly technology. The purposes of using these tools are different and manifold, starting from the didactic and touristic ones, up to the construction of workplaces that can be implemented and updated, which can also be used by technicians 
engaged in the constant maintenance of this product, which has many problems from the point of view of the conservation of the carved marble surfaces. For these reasons, the main advanced modelling techniques $w$, the main exchange software between BIM applications and gaming platforms such as Unreal Engine 4 and Uniti and the main VR and AR devices were tested with the general objective of facilitating and making it more interesting and accessible the discovery of the historical memory of the monument. Thanks to an open-source development logic, it was possible to develop an editable VR-AR project at any time, allowing an informative expansion of the storytelling in addition to that proposed in this study.

Interactive Menu

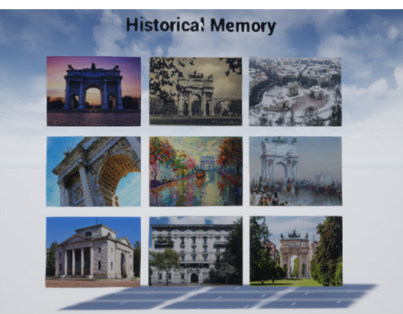

VR environment

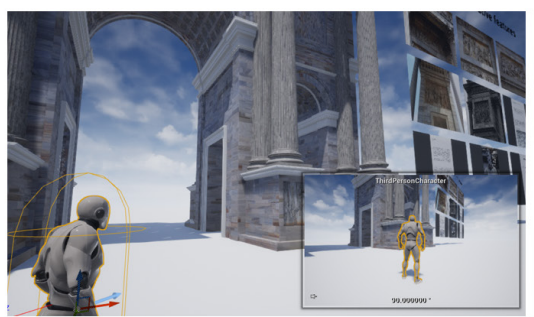

Interactive Menu

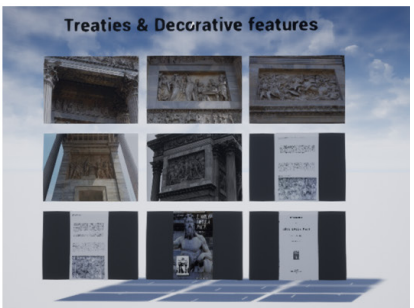

VR environment design Avatar for Mixed Reality

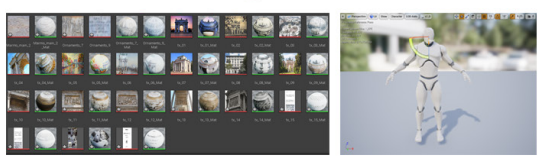

Visual scripting

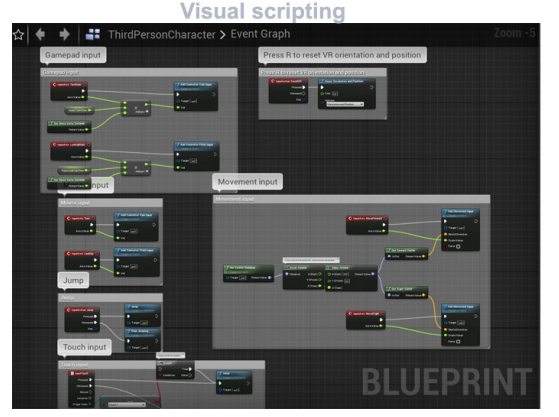

VR Objects from Scan-to-HIBIM process

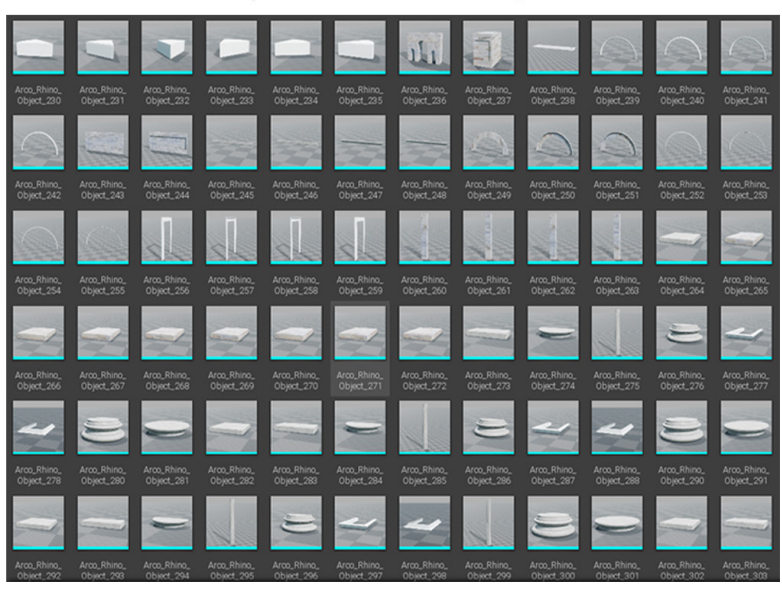

Fig. 6. The Mixed Reality project of the Arch of historic memory: from 3D survey and HBIM to mixed reality (VR-AR).
The reasons that led to the selection of specific devices and applications are as follows: - 3D drawing and free-form modelling: specific scan-to-BIM generative requirements were used, such as the grades of generation (GOG) 9 and 10 and NURBS algorithms, which made it possible to create geometric primitives and 3D models by directly interpolating the points that make up the scans and point clouds $(X)$. Mc Neel Rhinoceros was found to be the most complete both from the point of view of generative tools and as regards the exchange formats (it includes all the two-dimensional and three-dimensional exchange formats, proprietary and non-proprietary);

- object-oriented modelling: thanks to the use of the most used BIM application in the construction world (Autodesk Revit) it was possible to correctly apply the various GOGs of generation, transforming NURBS models into information parameter models;

- mixed reality: development of a VR-AR project through a complete gameplay scripting system based on the concept of using a node-based interface to create gameplay elements from within Unreal Engine Editor. As with many common scripting languages, it is used to define object-oriented $(\mathrm{O})$ classes or objects in the engine. Thanks to its flexibility it provides the ability for BIM experts to use virtually the full range of tools and concepts and generally only available to programmers.

- VR headset: the benefits of the Oculus RIFT S and Quest have made it possible to go beyond a simple desktop view. Thanks to the integration of movement sensors in the body 
of the VR mask and commands able to reproduce the main actions of the fingers (grip, release, selection, launch etc.) it was possible to increase the interactive levels of the HBIM model. Information panels, control points, and interactive objects have been created that can interact directly with the actions of the virtual user (fig. 6). Exchange formats (from Autodesk Revit to UE4) such as fbx. and obj. also made it possible to create a hyper-realistic digital environment. High-resolution images and orthophoto made it possible to map the monument in high resolution.

- mobile devices: the VR platform finally made it possible to select the main conversion techniques of the project developed entirely in UE4. Thanks to the main packaging functions, the MR project has been converted into a real app for IOS and Android devices.Virtual and Augmented reality were created to increase both the information level of the monument and the immersion levels of the virtual user.

\section{Conclusion}

In the last years, thanks to the interaction of scan to bim processes, it has been possible to go beyond the traditional two-dimensional representation, increasing the sharing and communication of information during the life cycle of buildings. Thanks to the benefits found in recent years in this specific field of application, this study has optimized the use of HBIM models with the aim of telling the story of the monument both remotely (desktop, VR headset) and on site (mobile phone and tablet), providing a study and analysis tool to industry experts such as restorers, maintainers, designers and developing an immersive environment capable of making the virtual user interact with the model of the monument and its information, becoming a real educational tool and entertainment.

\section{Notes}

[I] In this regard, we thank the architect Rebecca Fant for the valuable information provided, relating to the building site in progress (January 2020)

\section{References}

Andriasyan Mesrop et al. (2020). From Point Cloud Data to Building Information Modelling: An Automatic Parametric Workflow for Heritage. In Remote Sensing, 2020, 12.7: 1094.

Banfi Fabrizio (2017). BIM orientation: Grades of generation and information for different type of analysis and management process. In International Archives of the Photogrammetry, Remote Sensing \& Spatial Information Sciences, $2017,42$.

Banfi Fabrizio (2019). Hbim Generation: Extending Geometric Primitives and Bim Modelling Tools for Heritage Structures and Complex Vaulted Systems. In: 27th CIPA International Symposium-Documenting the Past for a Better Future. International Society for Photogrammetry and Remote Sensing, pp. I39- 148.

Banfi Fabrizio (2016). Building information modelling-A novel parametric modeling approach based on 3D surveys of historic architecture. In Euro-Mediterranean Conference. Springer, Cham, pp. I I6- 127.

Barazzetti Luigi et al. (20I5). Cloud-to-BIM-to-FEM: Structural simulation with accurate historic BIM from laser scans. In Simulation Modelling Practice and Theory, 2015, 57: 71-87.

Bertocci Stefano et al. (2020). The Kyrenia castle, an approach to digital documentation in the Cyprus island. In Proceedings of the 23rd International Conference on Cultural Heritage and New Technologies. Museen der Stadt Wien-Stadtarchäologie.

Brumana Raffaella et al. (2020). Survey and Scan to BIM Model for the Knowledge of Built Heritage and the Management of Conservation Activities. In Digital Transformation of the Design, Construction and Management Processes of the Built Environment. Springer, Cham, pp. 391-400.

Della Torre Stefano (2017). Un bilancio del progetto BHIMM. In Modellazione e gestione delle informazioni per il patrimonio edilizio esistente. Ingenio, pp. I0-16.

Elgewely Maha, Nadim Wafaa (2020). Immersive Virtual Reality Environment for Construction Detailing Education Using Building Information Modeling (BIM). In The IOth International Conference on Engineering, Project, and Production Management. Springer, Singapore, pp. $101-112$.

Fai Stephen et al. (20I I). Building information modelling and heritage documentation. In Proceedings of the 23rd International Symposium, International Scientific Committee for Documentation of Cultural Heritage (CIPA), Prague, pp. I2-I 6. 
Kiviniemi Arto et al. (20|8). Review of the development and implementation of IFC compatible BIM.

Liu Rui, Issa Raja R.A. (2012). Automatically updating maintenance information from a BIM database. In Computing in Civil Engineering 2012, pp. 373-380.

Murphy Maurice, McGovern Eugene, Pavia Sara (2013). Historic Building Information Modelling-Adding intelligence to laser and image based surveys of European classical architecture. In ISPRS journal of photogrammetry and remote sensing, 20I3, 76:89-102.

Oreni Daniela et al. (20|4). Survey turned into HBIM: the restoration and the work involved concerning the Basilica di Collemaggio after the earthquake (L'Aquila).In ISPRS annals of the photogrammetry, remote sensing and spatial information sciences, 2014, 2.5: 267.

Pepe Massimiliano et al. (2020). An Efficient Pipeline to Obtain 3D Model for HBIM and Structural Analysis Purposes from 3D Point Clouds. In Applied Sciences, 2020, 10.4: 1235

Previtali Mattia, Banfi Fabrizio (2018). Towards the Definition of Workflows for Automation in HBIM Generation. In EuroMediterranean Conference. Springer, Cham, pp. 52-63.

Previtali Mattia et al. (2020). An Ontology-Based Representation of Vaulted System for HBIM. In Applied Sciences, 2020, I0.4 1377

Pybus Cailen et al. (2019). New realities for Canada's parliament: a workflow for preparing heritage bim for game engines and virtual reality. In International Archives of the Photogrammetry, Remote Sensing \& Spatial Information Sciences.

Redmond Alan et al. (2012). Exploring how information exchanges can be enhanced through Cloud BIM. In Automation in construction, 2012, 24: 175- 183 .

Sdegno Alberto et al. (2018). Advanced Simulation of Frank Lloyd Wright's Fallingwater: Digital Reconstruction and Virtual Reality. In International and Interdisciplinary Conference on Digital Environments for Education, Arts and Heritage. Springer Cham, pp. 587-596.

Woodward Alexa, Heesom David (2020). Implementing HBIM on conservation heritage projects: Lessons from renovation case studies.

Wong Jing-Ying et al. (2020). BIM-VR Framework for Building Information Modelling in Engineering Education. In International Journal of Interactive Mobile Technologies (illM), 2020, 14.06: I5-39.

\section{Authors}

Fabrizio Banfi, Politecnico di Milano, fabrizio.banfi@polimi.it

Daniela Oreni, Politecnico di Milano, daniela.oreni@polimi.it

Jacopo Alberto Bonini, Politecnico di Milano, jacopoalberto.bonini@polimi.it

To cite this chapter: Banfi Fabrizio, Oreni Daniela, Bonini Alberto Jacopo (2020). L'arco della Pace di Milano e la sua memoria storica: dal rilievo 3D e HBIM alla mixed reality (VR-AR)/The Arch of Peace of Milan and its historic memory: from 3D survey and HBIM to mixed reality (VR-AR). In Arena A., Arena M., Brandolino R.G., Colistra D., Ginex G., Mediati D., Nucifora S., Raffa P. (a cura di). Connettere. Un disegno per annodare e tessere. Atti del $42^{\circ}$ Convegno Internazionale dei Docenti delle Discipline della Rappresentazione/Connecting. Drawing for weaving relationships. Proceedings of the 42 th International Conference of Representation Disciplines Teachers. Milano: FrancoAngeli, PP. $1660-1677$. 